\title{
Pengembangan Konsep Kompensasi Dosen dengan mekanisme reward/punishment ditopang dengan konsep sustainabilitas keuangan dengan menggunakan Sistem Informasi (Studi Kasus : Universitas X)
}

\author{
http://dx.doi.org/10.28932/jutisi.v5i2.1739 \\ Radiant Victor Imbar ${ }^{\bowtie 1}$ \\ ${ }^{\#}$ Jurusan S1 Sistem Informasi Universitas Kristen Maranatha \\ Jalan Suria Sumantri No 65 Bandung \\ ${ }^{1}$ radiant.vilit.maranatha.edu
}

\begin{abstract}
The performance of $\mathrm{X}$ University in addition to being measured by academic productivity, is also measured by the competence of academic staff. Career development, productivity and performance of $\mathbf{X}$ University employees (especially lecturers) is the key to $X$ University development strategies towards 2034. So there is a need to build a fix take home pay compensation concept solution with a more valid concept, more effective as a reward / punishment mechanism, and supported by concepts financial sustainability. In addition, the concept must be implemented to an information system that supports fix take home pay compensation to enter lecturer work plans and provides reports on the results of lecturer achievements each semester.
\end{abstract}

Keywords- compensation system, lecturer, information system

\section{Pendahuluan}

Manajemen Sumber Daya Manusia (SDM) bagi sebuah Perguruan Tinggi adalah urat nadi bagi keberlangsungan Perguruan Tinggi tersebut. Dosen merupakan aset penting bagi setiap Perguruan Tinggi.

Dosen adalah pendidik profesional dan ilmuwan dengan tugas utama mentransformasikan, mengembangkan, dan menyebarluaskan ilmu pengetahuan, teknologi, dan seni melalui pendidikan, penelitian, dan pengabdian kepada masyarakat menurut UU RI Nomor 14 Tahun 2005 tentang Guru dan Dosen. Jadi dari definisi dosen menurut UU RI diatas maka seorang dosen harus melakukan Tridharma perguruan tinggi yaitu Pendidikan, Penelitian dan Pengabdian Kepada Masyarakat. [1]

Universitas $\mathrm{X}$ memiliki misi (i) mengembangkan nilai-nilai hidup kristiani (NHK), (ii) menguasai dan mengembangkan ilmu pengetahuan, teknologi,dan seni, (iii) mendidik cendekiawan dengan NHK dan IPTEKS, sehingga berkarir sebagai agen Maranatha dalam membangun dunia kerja dan masyarakat dengan kekayaan nilai NHK. Sehingga misi Universitas X sejalan dengan UU RI No 14 th 2005 bahwa seorang dosen perlu mengembangkan, menyebarluaskan ilmu pengetahuan, teknologi dan seni melalui tridarma Perguruan Tinggi. Undang-Undang No. 14 Tahun 2005 tentang Guru dan Dosen, dalam pasal 51 ayat 1 huruf d menyatakan bahwa dalam melaksanakan tugas keprofesionalannya, dosen berhak memperoleh kesempatan untuk meningkatkan kompetensi, akses ke sumber belajar, informasi, sarana dan prasarana pembelajaran, serta penelitian dan pengabdian kepada masyarakat. [1]

Dosen saat ini diharapkan menjadi pakar dalam bidang kajian ilmunya dari proses penelitian kemudian disampaikan ke mahasiswa melalui pengajaran dan selain itu dibagikan ke masyarakat lewat pengabdian kepada masyarakat. Saat ini di Universitas $\mathrm{X}$ tingkat penelitian dosen masih rendah sehingga perlu ada kebijakan dari Universitas untuk mendorong dosen-dosen melakukan penelitian sehingga dosen-dosen dapat memproses kenaikan jabatan akademiknya. [2]

\section{RUMUSAN MASALAH}

Kinerja Universitas $\mathrm{X}$ selain diukur dari produktivitas akademik, juga diukur dari kompetensi staf akademik. 
Pengembangan karir, kompetensi, produktivitas dan kinerja pegawai Universitas $X$ (terutama dosen) adalah kunci strategi pengembangan Universitas X menuju Universitas X 2034. Namun kinerja ini menuntut produktivitas pegawai (terutama dosen) dalam suatu sistem kinerja, termasuk di dalamnya sistem kompensasi yang baik dan sustain.

Saat ini struktur kompensasi di Universitas X kurang efektif dan efisien dalam memacu kinerja Universitas X karena mengandung kelemahan (dapat dilihat di Gambar 1):

1. kurang memiliki dasar konseptual yang memicu pertumbuhan karir, kompetensi, produktivitas, kinerja, dan kesejahteraan secara terpadu.

2. kurang efektif sebagai instrumen rewards and punishment

3. kurang didukung oleh konsep sustainabilitas finansial

4. membebani administrasi payroll karena bervariasinya jumlah take home pay bulanan.

Akibatnya produktivitas dosen masih terbatas hanya pada pengajaran dan pengembangan karir dan kompetensi tidak berjalan dengan bergairah karena penelitian dan pengabdian masih dilakukan terbatas.

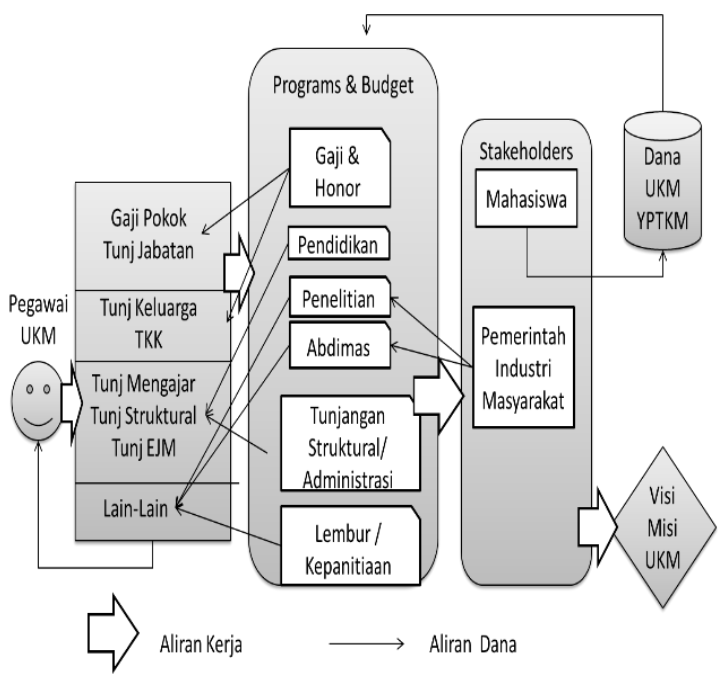

Gambar 1. Struktur Kompensasi di Universitas X [3]

Konsep kompensasi saat ini kurang sustainable karena tidak didukung pemasukan yang seimbang, komponen kompensasi tidak mencerminkan imbalan terhadap penugasan, serta tidak ditegakkan kewajiban bekerja waktu penuh $40 \mathrm{jam} /$ minggu.

Selain itu saat ini belum ada sistem informasi yang dapat menyimpan rencana beban kerja dosen selama 1 semester dan ketika akhir semester akan diperiksa apakah dosen tersebut sudah melakukan kewajibannya sebagai seorang dosen.

\section{TUJUAN}

Untuk menjawab Rumusan Masalah diatas maka perlu :

1. Diusulkan sebuah solusi konsep kompensasi yang bersifat fixed take home pay dengan konsep yang lebih valid, lebih efektif sebagai mekanisme reward/punishment, serta ditopang konsep sustainabilitas keuangan.

2. Pembuatan sistem informasi untuk mencatat rencana beban kerja dosen, mencatat setiap kewajiban pekerjaan yang dilakukan oleh dosen dan di akhir semester memberikan laporan ke Dekan terkait hasil kerja dosen tersebut.

\section{IV.DASAR TEORI}

Sistem Informasi adalah suatu sistem yang didukung oleh Teknologi Informasi didalam organisasi untuk mengelola transaksi sehari-hari dan menghasilkan laporanlaporan yang diperlukan oleh organisasi untuk membantu pengambilan keputusan. [4]

Manajemen adalah proses kerjasama antar individu dalam rangka mencapai tujuan-tujuan yang sudah ditetapkan sebelumnya. Proses Manajemen terdiri dari proses PPEPP perencanaan, pelaksanaan, evaluasi, pengendalian dan peningkatan. [5]

Manajemen Sumber daya manusia adalah proses merencanakan, mengorganisir, mengarahkan, mengendalikan pengadaan, pengembangan, kompensasi, dan pemberhentian karyawan dengan tujuan akhir mencapai tujuan karyawan, organisasi dan masyarakat yang ingin dicapai. [5]

Undang-undang Republik Indonesia Nomor 14 tahun 2005 tentang Guru dan Dosen, pasal 1, dikatakan bahwa dosen adalah pendidik profesional dan ilmuwan dengan tugas utama mentransformasikan, mengembangkan, dan menyebarluas-kan ilmu pengetahuan, teknologi, dan seni melalui pendidikan, penelitian, dan pengabdian kepada masyarakat. [1]

Aturan diatas menyebabkan profesi dosen bukan hanya merupakan seorang pendidik profesional pada perguruan tinggi, namun pada saat bersamaan seorang dosen juga merupakan ilmuwan dan pelopor dalam kegiatan pengabdian pada masyarakat. [2]

Tugas dosen tetap dalam melaksanakan tridharma perguruan tinggi memiliki beban kerja 12 (dua belas) SKS dan maksimal 16 (enam belas) SKS setiap semester. [2]

Saat ini di Universitas $\mathrm{X}$, beban tugas melakukan tridharma perguruan tinggi dinyatakan dengan Ekivalensi Jam Mengajar yang setara dengan 36 jam per minggu yaitu jam kerja wajib bagi seorang dosen. Kegiatan/Beban Kerja Dosen (BKD) $12 \mathrm{SKS} / \mathrm{semester}$ setara dengan $12 \mathrm{EJM}$ 
selama 26 minggu dalam satu semester ( 1 tahun terdiri dari 2 semester @ 26 minggu) yang berarti 312 EJM/semester.

\section{Kompensasi}

Kompensasi merupakan balas jasa yang diberikan oleh organisasi/perusahaan kepada pegawai, yang dapat berupa finansial maupun non finansial, pada periode yang tetap. Sistem kompensasi yang tepat dan sustain dari sisi keuangan akan mampu memberikan kepuasan bagi pegawai dan memungkinkan perusahaan memperoleh, memperkerjakan dan mempertahankan pegawai yang berprestasi. [6]

Sebagai bagian dari manajemen SDM, pemberian kompensasi bertujuan untuk : [6]

1. Memperoleh karyawan yang memenuhi persyaratan.

2. Mempertahankan karyawan yang ada.

3. Menjamin keadilan

4. Menghargai perilaku yang diinginkan.

5. Mengendalikan biaya.

6. Memenuhi peraturan-peraturan legal.

Jenis kompensasi yaitu : [7]

1. Kompensasi Langsung

Kompensasi langsung adalah penghargaan yang diterima pegawai dalam bentuk uang. Kompensasi langsung dapat berupa upah, gaji, insentif dan tunjangan lainnya.

2. Kompensasi tidak Langsung

Kompensasi tidak langsung adalah imbalan finansial yang tidak tercakup dalam kompensasi langsung seperti asuransi kesehatan.

Menurut Handoko [8] :Kompensasi tidak langsung adalah balas jasa pelengkap yang diberikan dalam bentuk pelayanan pegawai karena diperlakukan sebagai upaya penciptaan kondisi dan lingkungan kerja yang menyenangkan.

Istilah kompensasi sering disamaartikan dengan istilah renumerasi. Sistem kompensasi yang baik adalah sistem yang mampu menjaga kepuasan pegawai dalam bekerja memberikan yang terbaik yang pada gilirannya memungkinkan organisasi/perusahaan memperoleh, memelihara dan mempekerjakan pegawai dengan sikap dan perilaku positif bekerja secara produktif untuk kepentingan organisasi/ perusahaan.

Kompensasi dapat dilakukan dengan cara [9] :

1. Pembayaran gaji berdasarkan jabatan (Pay per Position) artinya gaji yang dibayarkan mengacu pada harga sebuah posisi atau jabatan. Idealnya perusahaan harus memiliki gambaran mengenai harga setiap jabatan yang dimiliki. Harga jabatan ini bersifat vertikal artinya semakin tinggi sebuah jabatan maka tentu gajinya akan semakin besar.

2. Pembayaran gaji berdasarkan kompetensi individu yang bersangkutan (Pay per Person) artinya bahwa besaran gaji juga harus dibedakan berdasarkan kompetensi individu yang bersangkutan. Artinya meskipun seseorang memegang jabatan/posisi yang sama msisalnya, sama-sama direktur, kedua orang ini dapat memiliki gaji yang berbeda berdasarkan level kompetensi yang dimiliki.

3. Pembayaran gaji berdasarkan kinerja ( Pay per Performance) artinya bahwa besaran gaji yang dibayarkan berdasarkan aspek kinerja atau hasil kerja dari karyawan. Konsep ini mensyaratkan perusahaan untuk menerapkan sistem indikator kinerja kunci dalam menilai kinerja setiap karyawannya.

Untuk mencapai profesionalisme dosen maka Universitas X membuat sebuah solusi konsep kompensasi yang bersifat fixed take home pay dengan konsep yang lebih valid, lebih efektif sebagai mekanisme reward/punishment, serta ditopang konsep sustainabilitas keuangan. Hal ini dibuat karena sistem kompensasi saat ini kurang efektif dan efisien dalam memacu kinerja Universitas X karena mengandung kelemahan:

1. Kurang memiliki dasar konseptual yang memicu pertumbuhan karir, kompetensi, produktivitas, kinerja, dan kesejahteraan secara terpadu.

2. Kurang efektif sebagai instrumen rewards and punishment

3. Kurang didukung oleh konsep sustainabilitas finansial.

4. Membebani administrasi payroll karena bervariasinya jumlah take home pay bulanan.

Akibat yang nyata adalah produktivitas dosen melakukan karya tridharma hanya terbatas pada mengajar mata kuliah, itupun dengan inefisiensi yang cukup tinggi. Kemudian, pengembangan karir dan kompetensi tidak berjalan dengan bergairah sehingga karir dosen dalam kenaikan jabatan akademik terhenti.

Untuk mendukung produktivitas dosen dalam melakukan karya Tridharma maka pimpinan Universitas Kristen Maranatha mengeluarkan SK Nomor: 042/SK/MNJ/UKM/XII/2018 mengenai Pedoman Penerapan Ekivalen Jam Mengajar Beserta Pemenuhan Kewajiban Ekivalen Jam Mengajar Bagi Dosen di Universitas X .

Ekivalen Jam Mengajar (EJM) adalah besaran yang mengekivalenkan honorarium berbagai kegiatan Dosen dalam melaksanakan kegiatan Tridharma Perguruan Tinggi 
terhadap honorarium hadir memberi kuliah. Kegiatan/Beban Kerja Dosen (BKD) 12 SKS/semester setara dengan 12 EJM selama 26 minggu dalam satu semester (1 tahun terdiri dari 2 semester@ 26 minggu) yang berarti 312 EJM/semester. [10]

Di Universitas X kategori dosen dibagi menjadi 3 jalur yaitu jalur Dosen Pengajaran, Dosen Penelitian dan Dosen Kepemimpinan. Dosen Pengajaran adalah dosen yang tertarik dalam melakukan Tridharma PT yang berhubungan dengan Pengajaran. Dimana Penelitian yang dilakukan oleh Dosen jalur Pengajaran adalah Penelitian yang berhubungan dengan Bahan ajar dan metode Pengajaran. Dosen Penelitian adalah dosen yang tertarik melakukan Tridharma PT yang berhubungan dengan Penelitian. Dosen jalur Kepemimpinan adalah dosen yang menjadi Pejabat Struktural Universitas X .

Dosen yang masuk ke dalam Kategori Dosen Pengajaran harus melakukan kegiatan Tridharma Perguruan Tinggi setara 312 EJM dengan komposisi Pendidikan minimal 196 EJM, Penelitian dan Pengabdian Masyarakat minimal 64 EJM dan Penunjang. [10]

Dosen yang masuk ke dalam Kategori Dosen Penelitian harus melakukan kegiatan Tridharma Perguruan Tinggi setara 312 EJM dengan komposisi Penelitian dan Pengabdian Masyarakat minimal 128 EJM, Pendidikan minimal 156 EJM dan Penunjang [10]

Dosen yang masuk ke dalam Kategori Dosen Kepemimpinan harus melakukan kegiatan pengabdian kepada masyarakat (menjabat struktural di Universitas X) minimal 94 EJM, Pendidikan dan Penelitian tidak boleh kosong. [10]

Universitas $\mathrm{X}$ juga memberlakukan kewajiban untuk setiap dosen untuk melakukan pengembangan diri. Pengembangan diri perlu dilakukan oleh masing-masing dosen agar kompetensi dosen tersebut bisa meningkat.

Berikut adalah pengembangan diri yang harus dilakukan semua dosen : [10]

- Mengembangkan spiritualitas NHK-ICE

- Mengikuti pengembangan Kepemimpinan

- Mengikuti pengembangan

$$
\begin{array}{ll}
\circ & \text { Keilmuan/ } \\
\circ & \text { Profesional/ } \\
\circ & \text { Sosial, kebangsaan. }
\end{array}
$$

- Membuat Roadmap Penelitian dan Keahlian/Kompetensi (termasuk rencana studi lanjut)

- Mentoring dosen yang memiliki jafung lebih rendah utk naik jafung (min Lektor)

Berikut adalah pengembangan diri yang harus dilakukan oleh Dosen Pengajaran [10] :

- Mengembangkan bahan ajar Digital
- Melakukan penelitian yang berkaitan dengan pembelajaran digital, dll

- Mengikuti kegiatan yang berhubungan dengan pengembangan mahasiswa (Contoh Menjadi pembicara utk mhs)

- Mengikuti kegiatan yang berhubungan dengan pengabdian kepada masyarakat

Berikut adalah pengembangan diri yang harus dilakukan oleh Dosen Penelitian [10] :

- Membuat Proposal Riset berbasis roadmap penelitian.

- Mencari dana hibah riset.

- Membentuk tim riset penelitian termasuk melibatkan mahasiswa (mis Tugas Akhir)

- Menjalankan isi proposal

- Menghasilkan luaran penelitian

- Menjadi mentor bagi peneliti pemula.

Berikut adalah pengembangan diri yang dilakukan oleh Dosen Kepemimpinan [10] :

- Melakukan pengembangan Sosio Enterpreneurship, management,

- Menerapkan ilmu pengetahuan di masyarakat, institusi dan industri.

- Menjadi mentor bagi calon Leader yang akan datang.

- Meningkatkan kualitas/keberhasilan organisasi di Universitas $\mathrm{X}$ (mencapai sasaran strategis dan mutu Universitas X )

- Menghasilkan nilai-nilai, termasuk nilai - nilai Ekonomi/Finansial seperti mendatangkan kontrak2 pekerjaan bagi Universitas $\mathrm{X}$.

\section{IMPLEMENTASI}

Setiap pegawai menerima kompensasi yang besarnya ditentukan oleh suatu target kinerja tahunan sesuai jabatannya. Target kinerja dihitung dalam poin atau skor EJM, yang terkait langsung dengan beban kerja dosen (BKD) Universitas X sesuai ketentuan.

Gambar 2 adalah gambar Sistem Kompensasi yang sustainable. 


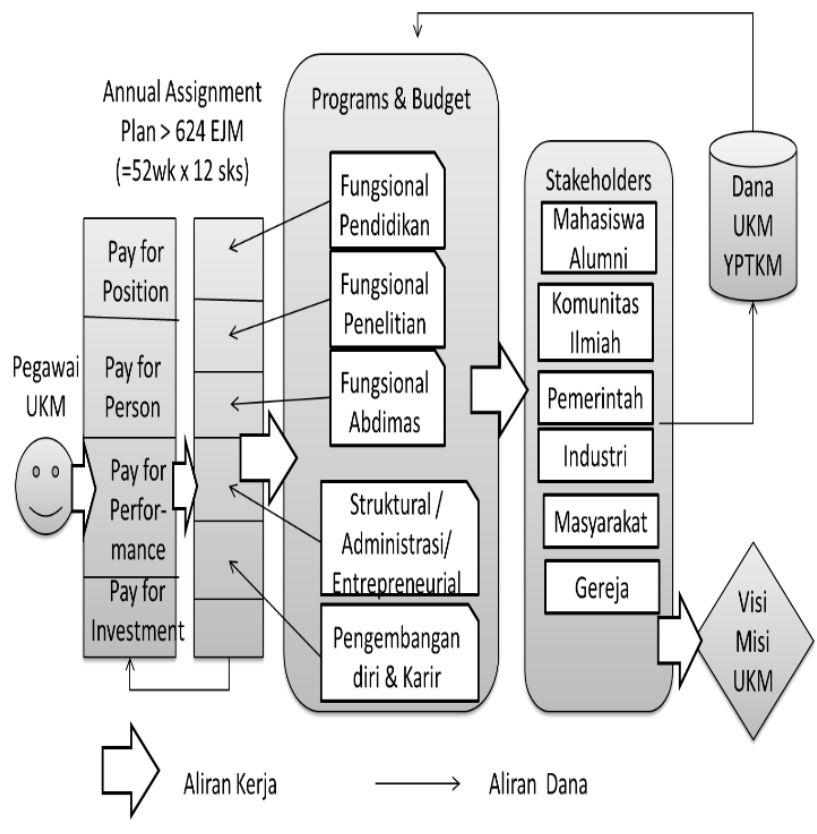

Gambar 2 Sistem Kompensasi yang sustainable [3]

Kompensasi yang diimplementasikan di Universitas $\mathrm{X}$ adalah kombinasi dari empat konsep sebagai berikut :

1. Pay for Position, berupa kompensasi dengan kewajiban menghasilkan kinerja yang baik. Komponen dari kompensasi ini adalah:

i. Gaji Pokok

ii. Tunjangan Jabatan

iii. Tunjangan Profesi Dosen (dari Negara)

2. Pay for Person, berupa kompensasi yang bergantung dari kondisi keluarga serta kompetensi, track record, dan karir pegawai. Komponen dari kompensasi ini adalah:

i. Tunjangan Keluarga

ii. Tunjangan Profesional (ctt: TKK diintegrasikan ke dalam Tunjangan Profesional ini)

3. Pay for Performance, berupa kompensasi yang bersifat variable untuk kinerja lebih (seperti lembur) dan prestasi luar biasa. Komponen dari kompensasi ini adalah:
i. Tunjangan Kinerja Unit/UKM
ii. Tunjangan Kinerja Individu
iii. Tunjangan Prestasi

4. Pay for Investment, berupa bonus insidental bagi mereka yang nyata melakukan perubahan besar, mendatangkan dana, serta melakukan penghematan yang bersifat menetap. Komponen dari kompensasi ini adalah:
i. Bonus Transformasi Institusi
ii. Bonus Investasi Finansial
iii. Bonus Inovasi Nilai

Besar setiap komponen kompensasi ditentukan tabel-tabel atau formula berdasarkan jenjang -jenjang.

a. Besar Gaji Pokok, ditentukan Jenjang Golongan dan Masa Kerja

b. Besar Tunjangan Jabatan, ditentukan Nilai Jabatan

c. Besar Tunjangan Profesi Dosen, diatur dalam ketentuan pemerintah

d. Besar Tunjangan Keluarga, dihitung menurut sebuah formula dan tabel.

e. Besar Tunjangan Kinerja Unit/Universitas X , dihitung berdasarkan proporsi Point Kontribusi Kerja dari Total Bonus Unit/Universitas X yang ditetapkan untuk Unit/Universitas $\mathrm{X}$, bila ada

f. Besar Tunjangan Kinerja Individu, dihitung berdasarkan formula atau table untuk kinerja lebih, bila ada.

g. Besar Tunjangan Prestasi, dihitung berdasarkan aturan table, kriteria dan ketegori prestasi luar biasa, bila ada.

h. Besar Bonus Transformasi Institusi, dihitung berdasarkan persentasi dari nilai kontibusi penting yang dihasilkan bagi Universitas $X$

i. Besar Bonus Investasi Finansial, dihitung berdasarkan persentasi dari nilai finansial yang dihasilkan bagi Universitas $\mathrm{X}$

j. Besar Bonus Inovasi Nilai, dihitung berdasarkan persentase dari inovasi nilai, terutama penghematan finansial yang dihasilkan bagi Universitas $\mathrm{X}$

Proses penentuan kompensasi dilakukan sebagai berikut

1. Sebelum tahun anggaran dimulai, setiap pegawai memperoleh penetapan FTE-jam serta target kinerja pada jabatan nya.

2. Berdasarkan penetapan ini serta jenjangjenjang nya, ditetapkan rencana jumlah YFTP (yearly fixed takehome pay) berbasis Pay Per Performance + Pay Per Person untuk setahun

3. Pegawai memasukkan rencana kinerja yang mencapai target kinerja, yang divalidasi oleh sumber-sumber anggaran. 
4. Rencana kinerja yang sudah divalidasi ini ditetapkan sebagai target kinerja tahun anggaran berjalan.

5. Kompensasi dibayarkan bulanan sebesar YFTP/12.

6. Setiap saat kinerja dapat dikumpulkan dan dilaporkan

7. Di akhir tahun kinerja dievaluasi.

i. Apabila target kinerja dicapai maka skema diulang, mulai poin (b)

ii. Apabila kinerja terlampau, maka dapat terjadi promosi FTE-xjam dengan target kinerja baru, lalu dilanjutkan ke poin (b)

iii. Apabila kinerja tidak tercapai, maka terjadi demosi FTE-xjam sesuai pencapaian.

\section{Instrumen Rewards \& Punishment}

1. Dengan konsep ini, maka

a. pegawai berkinerja FTE baik akan mendapatkan kompensasi tetap

b. pegawai berkinerja FTE melebihi standar akan menerima kompensasi lebih atau naik jenjang FTE-jam

c. pegawai berkinerja kurang akan mendapatkan demosi FTE-jam, yang akhirnya diberhentikan

2. Kenaikan komensasi juga terjadi akibat kenaikan jenjang

a. Dengan berjalannya waktu maka terjadi kenaikan Ruang Waktu masa kerja pada Gaji Pokok

b. Dengan meningkatnya kompetensi maka terjadi promosi Pangkat, yang menaikkan Tunjangan Professional.

c. Dengan meningkatnya eselon Jabatan terjadi promosi Jabatan yang menaikkan Tunjangan Jabatan.

d. Meningkatnya produktivitas/kinerja melebihi standar akan menaikkan Tunjangan Kinerja Individu.

e. Tercapainya prestasi luar biasa akan menghasilkan Tunjangan Prestasi

f. Meningkatnya Poin Kontribusi Kinerja akan menghasilkan kenaikan proporsi dari Bonus Kinerja Unit/Universitas X

g. Kontribusi yang bersifat penting bernilai dan menetap akan memperoleh Bonus
Transformasi Institusi yang adalah persentasi dari estimasi nilai yang dikontribusikan

h. Kontribusi dana akan mendapatkan Bonus Investasi

i. Inovasi nilai (seperti penghematan) akan mendapatkan Bonus Inovasi Nilai

Sistem Informasi Form Rencana Kerja (e-FRK) dibuat untuk mencatat Rencana Kerja Dosen di Universitas X dan akan menampilkan realisasi pencapaian EJM tiap semester serta menjalankan fix take home pay bagi Dosen.

Gambar 3 adalah gambar Form Login ke Sistem Informasi FRK.

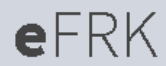

Silahkan masukan nama pengguna dan kata sandi untuk memulai aplikasi

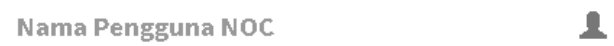

Kata Sandi

Masuk

(ㄷ [KCC85] 2018-2019 DLTI UK. Maranatha

Gambar 3 Login eFRK

Gambar 4 adalah gambar menu yang dimiliki di aplikasi eFRK. 


\section{$\leftarrow \rightarrow$ C A https:/egaji.maranat \\ Form Rencana Kerja}

Menu Operator

- Data Jalur Dosen

Menu Dekan

O Persetujuan Data Jalur Dosen

O Persetujuan Rencana EJM

\section{Menu Dosen}

O Data Input Rencana Dosen

O Data Input Pengembangan Diri

- Laporan Realisasi Dosen

\section{Menu KaProDi/SekProdi}

O Persetujuan Rencana EJM

\section{Menu LPPM}

\section{O Persetujuan Rencana EJM}

\section{Menu SDM}

- Lihat Track Dosen

Gambar 4. Menu Aplikasi e-FRK

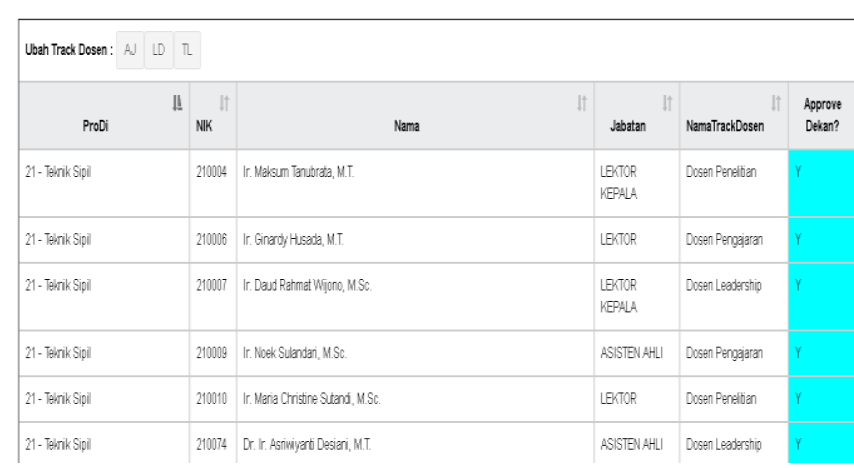

Gambar 5. Form Melihat Jalur Dosen

Gambar 6 adalah Gambar Menu untuk melakukan Approval Jalur Dosen yang dipilih apakah Dosen Pendidikan/Dosen Penelitian/Dosen Kepemimpinan yang dilakukan oleh Dekan.

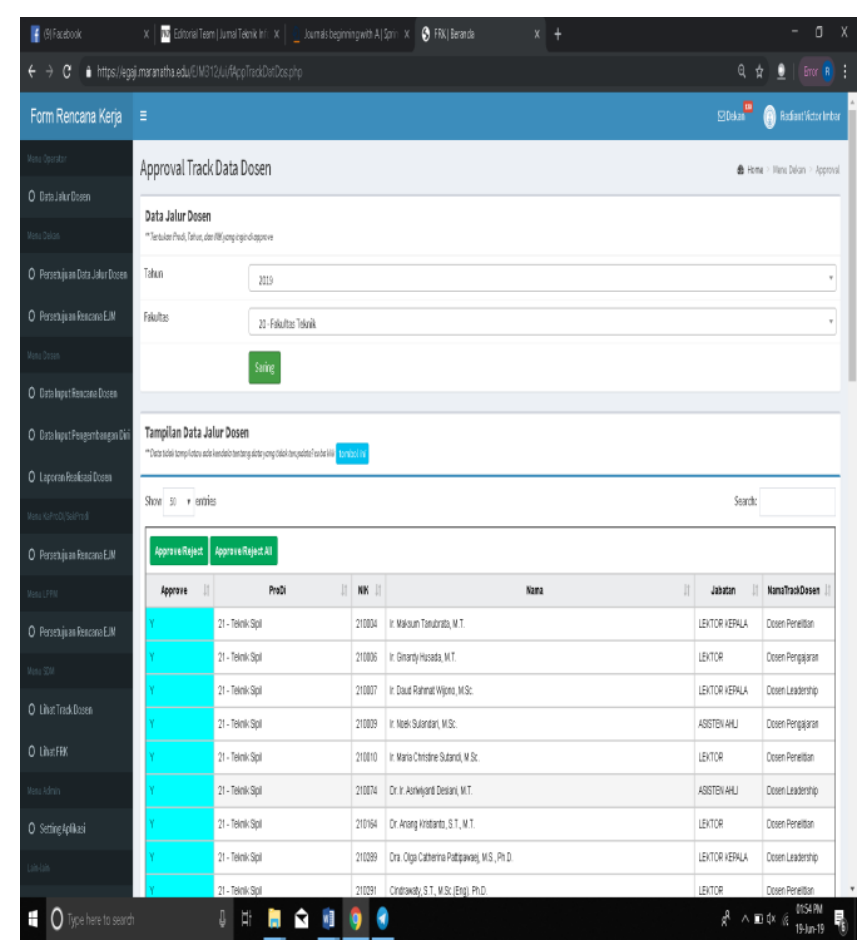

Gambar 6. Menu untuk Approval Jalur Dosen oleh Dekan.

Gambar 7 adalah gambar untuk mengisi FRK yang dilakukan dosen.

Gambar 5 adalah gambar yang menampilkan dosen-dosen yang termasuk dalam jalur Pengajaran/ Penelitian/Kepemimpinan. 


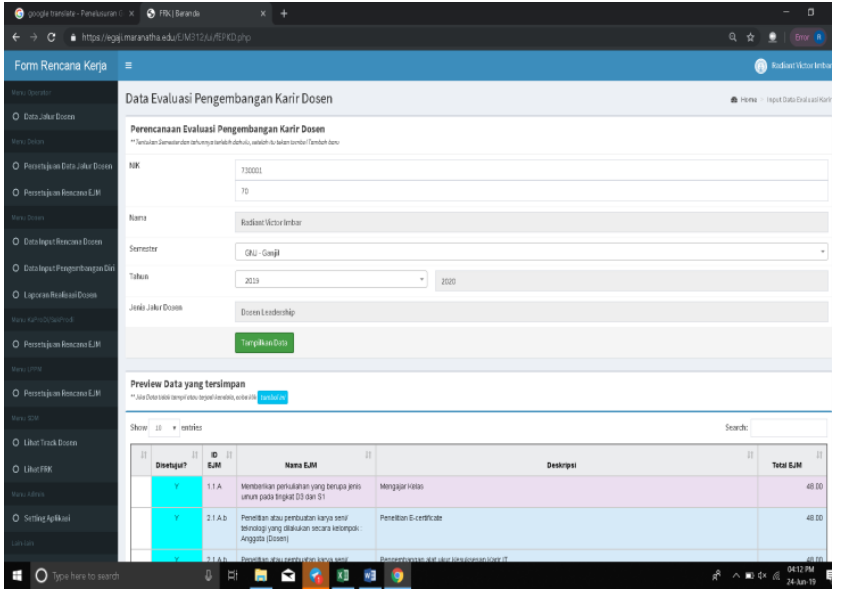

Gambar 7. Form Input FRK Dosen

Gambar 8 adalah Gambar Perencanaan FRK yang disetujui oleh Kaprodi

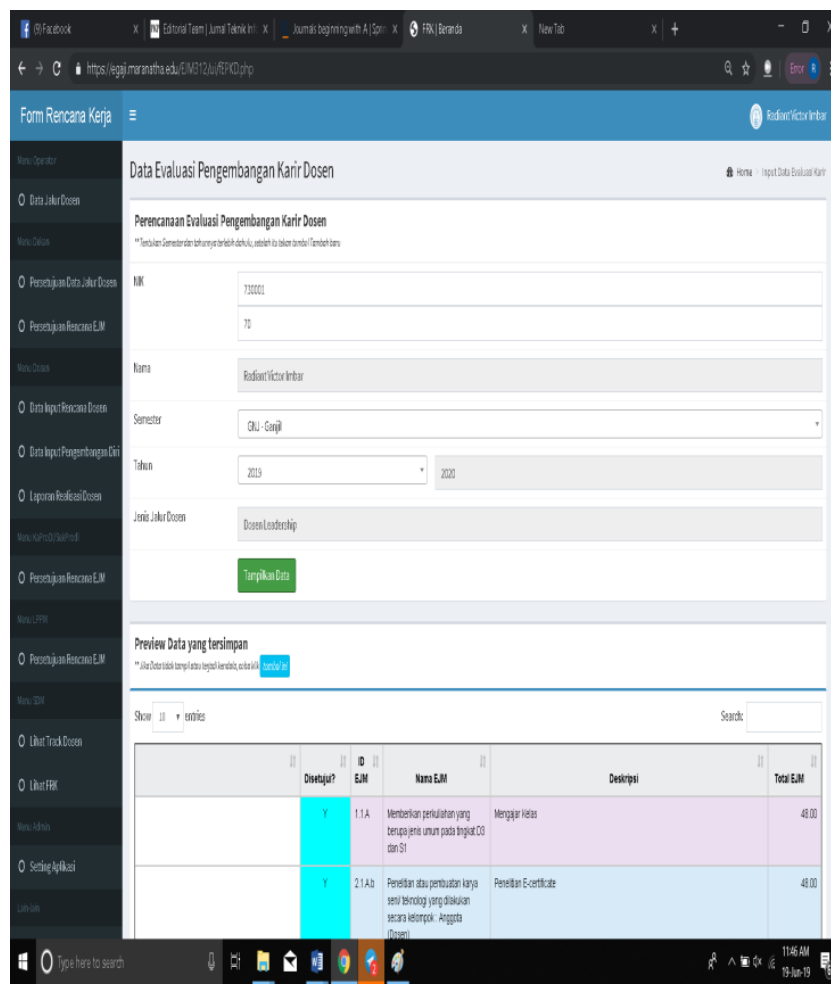

Gambar 8. Form Tampilan Perencanaan FRK yang sudah disetujui Kaprodi.

Gambar 9 adalah Gambar Aplikasi untuk memasukkan data pengembangan diri dosen yang harus dilakukan semua dosen tiap semester.

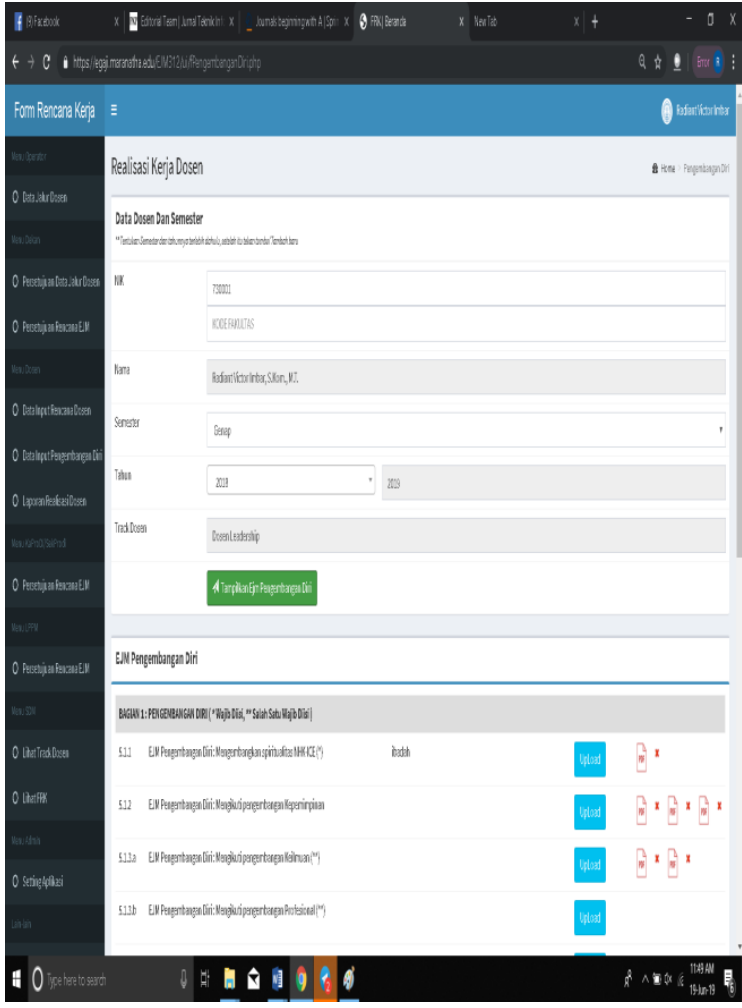

Gambar 9. Form Input Pengembangan Diri

Gambar 10 adalah Gambar hasil realisasi Dosen tiap semester.

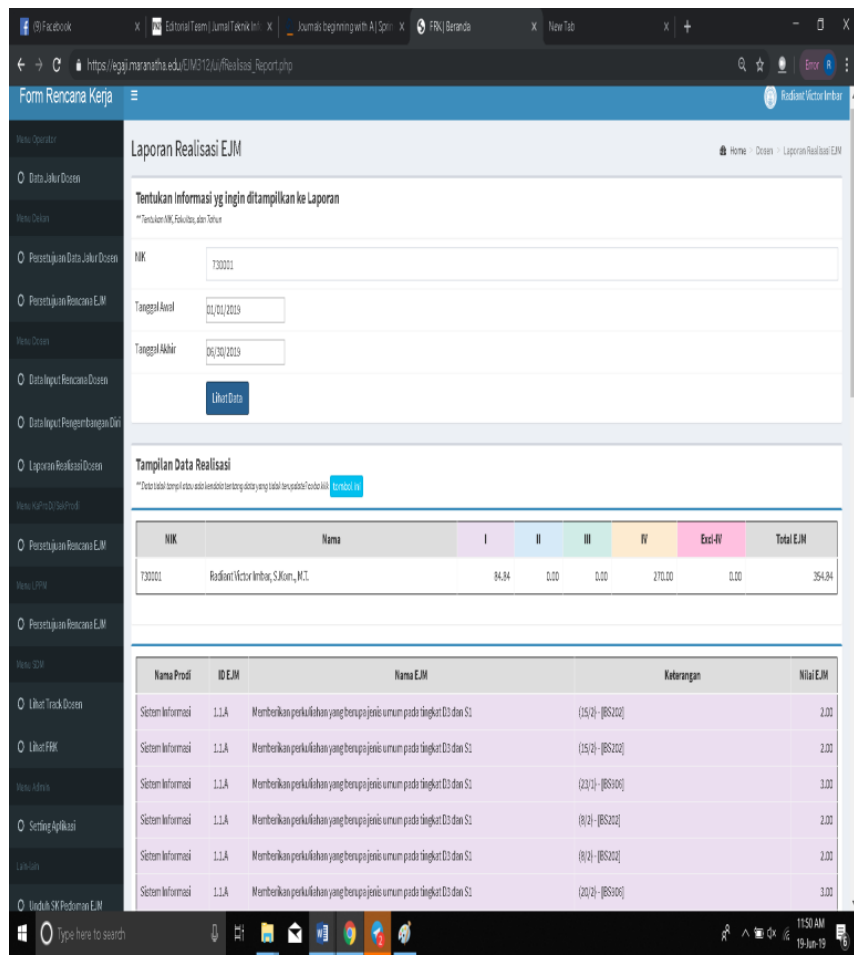

Gambar 10. Form Realisasi EJM 


\section{KESIMPULAN}

Konsep Kompensasi Fix Take Home Pay sudah dijalankan di semester Genap 2019/2020 di Universitas X . Untuk Sistem Reward dan Punishment sudah dijalankan saaat ini dimana apabila seorang dosen dapat berkinerja lebih dari 312 EJM maka akan ada reward yaitu EJM lebihnya dibayarkan sesuai tarif.

Untuk Sistem e-FRK akan dikembangkan terus terutama dari sisi keamanan data. Saat ini Sistem e-FRK sudah berfungsi dimana pencatatan rencana kerja dosen tiap semester bisa dilakukan oleh dosen secara online dan laporan realisasi setiap dosen bisa dilihat oleh masingmasing dosen.

Saat implementasi ada beberapa catatan yang perlu diperbaiki terutama apabila terjadi kesalahan input EJM oleh staf keuangan yang menyebabkan kesalahan dalam menghitung beban tridharma dosen. Selain itu prosedur pelaporan hasil karya dosen harus disosialisasikan kepada dosen sehingga mereka dapat mengerti alur pelaporan EJM ke sistem.

\section{UCAPAN TERIMA KASIH}

Terima kasih untuk Tim Teknologi Informasi Universitas $\mathrm{X}$ yang membantu membuat dan mengimplementasikan Sistem Informasi FRK dilingkungan Universitas X

\section{DAFTAR PUSTAKA}

[1] P. Indonesia, Undang Undang Republik Indonesia No 14, Jakarta: Sekretariat Negara, 2005.

[2] M. P. Dr. Arwildaryanto, Manajemen Sumber Daya Manusia Perguruan Tinggi; Pendekatan budaya kerja dosen profesional, IDEAS Publishing, 2012.

[3] M. P. Prof. Ir. Armein Z R Langi., Konsep Kompensasi Fix Take Home Pay versi 1, Bandung: Universitas Kristen Maranatha, 2016.

[4] T. Sutrabi, Konsep Sistem Informasi, Yogyakarta: CV Andi Offset, 2012.

[5] C. J. L. Gaol, A to Z Human Capital, Jakarta: PT Gramedia Widiasarana Indonesia, 2014.

[6] B. University, “sbm.binus.ac.id,” Binus University, 07082017. [Online]. Available: https://sbm.binus.ac.id/2017/08/07/bisnis-yangberkelanjutan/. [Accessed 0107 2019].

[7] M. Dr. Farida Elmi, Telisik Manajemen Sumber Daya Manusia, Mitra Wacana Media, 2018.

[8] S. M. Mila Badriyah, Manajemen Sumber Daya Manusia, Bandung: Pustaka Setia, 2015.

[9] N. Hadari, Perencanaan SDM, untuk Organisasi Profit yang kompetitif, Yogyakarta: Gadjah Mada University Press, 2000.

[10] D. P. S. A. Dickdick Sodikin, Manajemen Sumber Daya Manusia: Membangun Paradigma Baru, Jakarta: Salemba Empat, 2017.

[11] R. U. K. Maranatha, 042/SK/MNJ/UKM/XII/2018, Bandung: Universitas Kristen Maranatha, 2018. 